Удк 633.11

https://doi.org/10.32634/0869-8155-2020-337-4-56-59

Тип статьи: оригинальное исследование

Type of article: original research

Tamraz H. Tamrazov ${ }^{1}$,

Faiq A. Khudayev ${ }^{2}$

${ }^{1}$ Department of Plant Physiology and

Biotechnology, Research Institute of Crop

Husbandry

Baku, Azerbaijan

2 Department of Selection, Scientific Research Institute of Vegetable Growing Plant

Baku, Azerbaijan

E-mail: tamraz.tamrazov@mail.ru

${ }^{2}$ Department of Plant Breeding Research Institute of Crop Husbandry

Baku, Azerbaijan

E-mail: faiq03@mail.ru

Key words: drought, physiological indicators, plant physiology, photosynthesis, wheat genotypes.

For citation: Tamrazov T.H., Khudayev F.A. Morphophysiological parameters of late maturing wheat genotypes with various yield and dry resistance. Agrarian Science. 2020; 337 (4): 56-59. (In Russ.)

https://doi.org/10.32634/0869-8155-2020-337-4-56-59

There is no conflict of interests

Тамразов Т.Г. 1 ,

Худаев Ф.А. ${ }^{2}$

${ }^{1}$ ФГБОУВО «Тувинский государственный университет»

667000, Россия, Республика Тыва, г. Кызыл, ул. Ленина, д.36

E-mail: b.mongush@yandex.ru

${ }^{2}$ ФГБНУ «Всероссийский НИИ коневодства»

Россия, Рязанская область, Рыбновский

район, поселок Дивово, 20

E-mail: amzaitceff@mail.ru, atromiks-77@mail.ru

${ }^{3}$ Российский государственный аграрный университет - Московская сельскохозяйственная академия имени К.А. Тимирязева Москва, Россия

E-mail: zoo@rgau-msha.ru

Ключевые слова: засуха,

физиологические показатели, физиология растений, фотосинтез, генотипы пшеницы.

Для цитирования: Тамразов Т.Г., Худаев Ф.А. Морфофизиологические показатели позднеспелых генотипов пшеницы, отличающихся засухоустойчивостью и продуктивностью. Аграрная наука. 2020; 337 (7): 56-59.

https://doi.org/10.32634/0869-8155-2020-337-4-56-59

Конфликт интересов отсутствует

\section{Morphophysiological parameters of late maturing wheat genotypes with various yield and dry resistance}

\section{ABSTRACT}

The article considers the selection of high-yielding and drought-tolerant forms of genotypes with different morphological properties, different periods of ripeness under the influence of stress factors, development of recommendations for use as primary material in breeding. As the studied object, 12 wheat genotypes were used, divided by 4 genotypes in each group, differing by ripening periods. The results of the research allow direct assessment of drought resistance by a number of possible complex methods, which allow to predict not only various aspects of drought tolerance in the early stages of wheat development, but also their potential productivity.

\section{Морфофизиологические показатели позднеспелых генотипов пшеницы, отличающихся засухоустойчивостью и продуктивностью}

\section{PEЗЮME}

В статье рассматривается отбор высокоурожайных и засухоустойчивых форм генотипов с различными морфологическими свойствами, разными периодами зрелости под воздействием стрессовых факторов, разработка рекомендаций по использованию в качестве основного материала в селекции. В качестве исследуемого объекта было использовано 12 генотипов пшеницы, разделенных на 4 генотипа в каждой группе, различающихся по периодам созревания. Результаты исследования позволяют проводить прямую оценку устойчивости к засухе рядом возможных сложных методов, которые позволяют прогнозировать не только различные аспекты устойчивости к засухе на ранних этапах развития пшеницы, но и их потенциальную продуктивность. 


\section{INTRODUCTION}

Drought stress is the most important factor and the increasing problem limiting wheat (Triticum aestivum L.) in the world. Wheat has physiological mechanisms that allow adaptation of drought stress and may vary between different genotypes.

Recent accelerated global climate changes has led to environmental degradation, the development of stress factors such as droughts and salinization, the destruction of a number of valuable plant species in the flora, which can lead to serious food shortages and food shortages in the future.

Drought tolerance of plants is associated with the ability of them to adapt to dehydration and to resist overheating during the period of drought in natural conditions, which is based on the study of the water regime of plants $[1,2,11]$.

To date, the problem of drought tolerance of plants continues to be one of the urgent problems of plant physiology.

Periodic droughts occur in our country, however, a certain pattern in this, apparently, is not observed.

Due to the fact that the phase of plant development do not always coincide with physiological changes, it is necessary to establish more accurate and objective indicators of plant ontogenesis, which would allow a better, more accurate approach to the characterization of the physiological state of a plant at this stage of its ontogenesis. The stages of development of the vegetative and reproductive organs were used as such indicators $[1,6,7,10]$.

In recent years frequent acute drought in various regions of the country has become the cause of low productivity of all varieties of wheat and adversely affects its quality. Currently grain fields in the country are half-arid, non-irrigated and partly moisture-free non-irrigated regions $[3,5,8]$.

\section{MATERIALS AND METHODS}

Object of research: field studies were carried out during the 2018/19 growing season at the experimental field of the Department of Plant Physiology and Biotechnology Research Institute of Crop Husbandry, located in the Apsheron peninsula, Baku.

As a research object, durum and bread wheat genotypes introduced from local wheat genotypes and international breeding centers were taken.

As the studied object, 12 wheat genotypes were used divided by 4 genotypes in each group, differing by ripening periods.

The experiments were carried out in two versions:

1) under optimal irrigation conditions, 2) not irrigated conditions.

According to the ripening period, wheat genotypes were grouped as follows:

1. Genotypes of early ripening wheat varieties.

2. Genotypes of midle ripening wheat varieties.

3. Genotypes of late ripening wheat varieties.

In this study, only the dynamics of changes in the main physiological parameters of late maturing durum wheat and bread wheat genotypes under the influence of drought.

Durum wheat genotypes (Barakatli 95, Tartar) and bread wheat genotypes (Gyrmyzy gul 1, Tale 38) were grown under two conditions: drought (non-irrigation) and irrigated (three irrigations: at seedlings, stem elongation and grain filling).

Gas exchange parameters (photosynthesis rate - Pn, stomatal conductance - gs, intercellular $\mathrm{CO}_{2}$ concentration $\mathrm{Ci}$, transpiration rate $-\mathrm{E}$ ) were measured using $\mathrm{LI}-\mathrm{COR}$ 6400XT Portable Photosynthesis System (LI-COR Biosciences, Lincoln, NE, USA) at the anthesis growth stage.

\section{Physiological evaluation of wheat genotypes}

After applying the drought conditions, the appropriate amount of water for the flag leaf was measured to study the physiological changes. The fresh weight of the flag leaf (FW) was determined immediately after jaundice and then washed down in distilled water until complete water and drunken weight (TW). Turgid leaf was dried with hot owen at a constant heat of $105^{\circ} \mathrm{C}$ and dry weight (DW) was recorded.

$$
\text { RWC }(\%)=(F W-D W) /(T W-D W) \cdot 100 .
$$

The cholorofil meter (SPAD) was used to measure the relative chlorophyll content of the leaves. Five of the leaves of a plant have been read and their average for the determination of chlorophyll content has been taken into account. Content of chlorophyll was recorded in percent.

Statistical studies were conducted between a number of indicators to verify the accuracy of the results obtained during the research. Correlation relationship and regression model of spike elements were first constructed for structural analysis [5, 7].

\section{Statistical analysis}

In some years, droughts cover a vast area and, as a consequence, the sharp decline of all agricultural plants. It is known that when we say drought-resistant varieties, we mean that varieties can continue to be very small in soil and atmospheric water and produce high yields. Correlation among traits was calculated by SPSS 16 software.

\section{RESULTS AND DISCUSSION}

At present, in order to create resistant wheat varieties to drought and high temperature, modern methods are used to study the molecular genetic basis of stress resistance $[1,11]$.

Various hard and soft wheat varieties studied under natural conditions are not subjected to the influence of abiotic stress factors of the environment separately, but in a complex manner $[2,6,9]$. As a reaction to the consequence of drought, the selection of wheat by the ripening period is one of the main conditions.

The drought factor affects all metabolic processes of plants. During drought leaf photosynthetic gas assimilation, $\mathrm{CO}_{2}$, decreases $[8,10]$.

In our country, various hard and soft wheat genotypes are studied at the experimental base of the Azerbaijan Scientific Research Institute of Agriculture. During the study, the main physiological parameters (the rate of photosynthesis intensity, transpiration rate, stomata conductivity, $\mathrm{CO}_{2}$ saturation in the intercellular space) of three different groups according to the ripening period (early, middle, late) of high-yielding hard and soft wheat varieties were studied $[5,8,11]$.

The opening and closing of stomata on plant leaves is closely related to the intercellular supply of moisture, with changes in light and temperature. The processes of photosynthesis and transpiration in plants are regulated by the work of stomata. If they are open or slightly open, the gas exchange does not occur with the same intensity as in open surfaces $[1,5,11]$.

Arid climate enhances plant transpiration, resulting in leaves being dehydrated and transpiration stopped [1, 11]. With a stop of transpiration, the stomata of the leaves close. Therefore, due to the fact that $\mathrm{CO}_{2}$ is covered up, the process of photosynthesis.

The intensity of the photosynthesis process can be expressed in the following units: in milligrams of $\mathrm{CO}_{2}$, assimilated $1 \mathrm{dm}^{2}$ of leaf per 1 hour; in milliliters 02 , allocated $1 \mathrm{dm}^{2}$ of sheet per 1 hour; in milligrams of dry matter, accumulated $1 \mathrm{dm}^{2}$ of leaf per 1 hour. 
Methods for determining the intensity of photosynthesis are numerous. They are discussed in special manuals. When interpreting data obtained by any method, it should be borne in mind that in the light of plants not only photosynthesize, but also breathe. In this regard, all indicators measured by one method or another are the result of two opposite processes or the difference between the indicators of photosynthesis and respiration. This is visible photosynthesis $[1,4,9]$. So, for example, the observed change in $\mathrm{CO}_{2}$ content is the difference between the amount that is absorbed during photosynthesis and the amount that is released during breathing. In order to go to the true value of photosynthesis, in all cases it is necessary to make a correction that takes into account the intensity of the respiration process $[6,7$, 11]. In a natural setting, all factors interact with each other, i.e., the action of one factor depends on the tension of all the others. In general terms, this can be formulated as follows: a change in the tension of one factor, while the others remain unchanged, affects photosynthesis, starting from the minimum level at which the process begins and ending with the optimum, at which the process ceases to change (the curve reaches a plateau). In many cases, an increase in factor tension after a certain level even slows down the process $[2,6]$. However, if you start to change any other factor, then the optimal value of the tension of the first factor changes upwards. In other words, a plateau is reached at a higher tension value. The speed of the process, in particular the rate of photosynthesis, depends primarily on the intensity of the factor that is at the minimum (limiting factor) $[1,8]$. An example is the interaction of factors such as light intensity and $\mathrm{CO}_{2}$ content. The higher the carbon dioxide content (within certain limits), the higher the illumination, the photosynthesis indices reach a plateau $[4,11]$.

The purpose of the research is the selection of highyielding and drought-tolerant forms of genotypes with different morphological properties, different periods of ripeness under the influence of stress factors, development of recommendations for use as primary material in breeding $[3,5]$.

In the optimal irrigation regime, soil with a relative humidity of $70-80 \%$ was watered $2-3$ times during the growing season. It should be noted that in the non-irrigated version (drought) the soil was not watered, not exceeding moisture (35-55\%), aridity was artificially created.

In conditions of drought, due to an increase in turgor pressure and a decrease in water potential, an acute deficit of evaporation pressure is created in the atmosphere and stomata close (14).

With a lack of moisture, photosynthesis slows down mainly as a result of a decrease in stomata patency $[9,10]$. In the field, regulation of transpiration by stomata leads, as a primary reaction of plants to a lack of moisture, to a reduction in the amount of $\mathrm{CO}_{2}$ ingested by leaves $[2,7,11]$.

The main physiological parameters of the LI- 6400 of the studied different durum and bread wheat genotypes were studied using the mobile photosynthesis measuring system (Lİ-COR).

An increase in $\mathrm{CO}_{2}$ concentration has an inhibitory effect for various reasons. An increase in $\mathrm{CO}_{2}$ content causes stomata closure. High $\mathrm{CO}_{2}$ concentrations are especially unfavorable in high light conditions $[1,3,6]$ This suggests that $\mathrm{CO}_{2}$ in certain concentrations inhibits individual enzymatic reactions of the Calvin cycle. Under natural conditions, the content of $\mathrm{CO}_{2}$ is so small that it can limit the increase in the process of photosynthesis. This is especially pronounced at a sufficiently high light intensity, when dark reactions are limiting. It should be noted that in the daytime the $\mathrm{CO}_{2}$ content in the air around plants decreases. In this connection, an increase in the content of $\mathrm{CO}_{2}$ in the air is one of the important ways to increase the intensity of photosynthesis and, as a consequence, the accumulation of dry matter by a plant $[1,3,11]$. However, in the field, the regulation of $\mathrm{CO}_{2}$ content is difficult. In part, this can be achieved by enhancing the release of $\mathrm{CO}_{2}$ in the soil by applying organic fertilizers. It is easier to increase the content of $\mathrm{CO}_{2}$ in closed ground. In this case, feeding $\mathrm{CO}_{2}$ gives good results $[3,5]$.

The measurement results are shown in tables. Regarding table, it can be noted that the studied dynamics of various physiological parameters of early wheat genotypes have a certain ontogenetic coloration.

The tables show that durum and bread wheat varieties were studied. In all studied varieties, at the beginning of the growing season, the difference between the variants is not so great, but by the end of the growing season this difference is much larger. This is explained by the fact that in green leaves stomata patency well regulates the rate of transpiration and the intensity of photosynthesis.

By accelerating the rate of photosynthesis in the intercellular space, the concentration of $\mathrm{CO}_{2}$ decreases. Exacerbation of the drought factor exacerbates the difference between irrigated and non-irrigated options. The relationship between all the studied parameters leads to a decrease by the end of the growing season.

The table shows the following development phases that are more suitable for measurements: earing phase, spike formation, flowering, grain formation. Measurements were carried out mainly on two, seventh, and eighth tiers of the leaf organ of a plant. Since the beginning of the vegetative process (earing phase), the 7 th and 8 th leaf of the Barakatli-95 variety $\mathrm{Pn}-12.5 \%$ : $16.03 \%$ ( $\mu \mathrm{mol} \mathrm{CO}_{2}$ $\mathrm{m}^{-2} \mathrm{~S}^{-1}$, Gs $-2.6 \%: 13.1 \% \mathrm{~mol} \mathrm{H}_{2} \mathrm{O} \mathrm{m}^{-2} \mathrm{~S}^{-1}, \mathrm{Ci}-29.3 \%$ : $32.5 \% \mu \mathrm{mol} \mathrm{CO} 2 \mathrm{~mol} 1 / 2, \mathrm{E}-9.27 \%$ : $18.9 \%$, similarly, 7th and 8th leaf in Tartar variety $\mathrm{Pn}-17.8 \%: 21.6 \%$; Gs 10.2\%: 9.9\%; Ci - 30.2\%: 33.9\%; E - 1.2\%: 9.3\%.

Accordingly, in soft wheat varieties, changes occurred in the indicated interval. In both tiers of the Gyrmyzygul-1 grade $\mathrm{Pn}-10.2 \%$ : $4.07 \%$; Gs $-23.1 \%$ : $8.9 \%, \mathrm{Ci}-2.8 \%$ : 1.9\%; E - 8.3\%: 6.1\%; accordingly, varieties Tale-38 have changes in the range $\mathrm{Pn}-11.8 \%: 13.05 \%$, Gs $-32.5 \%$ : 20.6\%, Ci - 11.7\%: 2.1\%, E - 23.1\%: 24.2\%.

In contrast to the initial developmental phases, at the stage of grain formation, that is, by the end of the growing season, such an assessment was made based on differences between genotypes. The ratios for Barakatli-95, $\mathrm{Pn}-42.6 \%$ : 12.6\%, Gs - 34\%: $14 \%, \mathrm{Ci}-22 \%$ : 3\%, E - 36\%: $35 \%$, and Gyrmyzygul-1, Pn $-18 \%$ : $30 \%$ were determined; Gs $-24 \%$ : 27\%; Ci - 28\%: 20\%; E - 40\%: 41\%.

Based on the data presented, it can be noted that in the studied varieties, the difference between the variants according to the studied parameters at the beginning of the growing season was insignificant, but towards the end it increased. A particular decrease is observed in arid variants. And this is due to the fact that with acute lack of moisture, stomata patency decreases, photosynthesis processes fade. When comparing varieties, Gobustan was less stable.

The study of the nature of the formation of the assimilation 1 photosynthetic apparatus of soft wheat, which has the highest variety diversity, is necessary for the targeted creation of environmentally and economically more profitable varieties. Peculiarities of donor-acceptor relations in the process of forming a wheat crop in a varietal section have not been sufficiently studied and need extensive study to search for unique genotypes. 


\begin{tabular}{|c|c|c|c|c|c|c|c|c|c|c|c|c|c|c|c|c|c|c|}
\hline \multirow{3}{*}{$\begin{array}{l}\text { Name of } \\
\text { genotype }\end{array}$} & \multirow{3}{*}{ 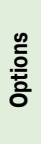 } & \multirow{3}{*}{$\begin{array}{l}\text { ఏ } \\
\text { స్తు }\end{array}$} & \multicolumn{16}{|c|}{ Phase of development } \\
\hline & & & \multicolumn{4}{|c|}{ Phase stem elongation } & \multicolumn{4}{|c|}{ Phase flowering } & \multicolumn{4}{|c|}{ Phase antihesis } & \multicolumn{4}{|c|}{ Phase grain filling } \\
\hline & & & Pn & Gs & $\mathbf{C i}$ & $\mathbf{E}$ & Pn & Gs & $\mathrm{Ci}$ & $\mathbf{E}$ & Pn & Gs & $\mathrm{Ci}$ & E & Pn & Gs & $\mathrm{Ci}$ & E \\
\hline \multirow{4}{*}{ Barakatli-95 } & \multirow{2}{*}{1} & 8 & 10,6 & 0,382 & 342 & 4,13 & 19,5 & 0,433 & 361 & 6,55 & 20,2 & 0,401 & 387 & 8,22 & 17,6 & 0,443 & 416 & 106 \\
\hline & & 7 & 9,8 & 0,362 & 351 & 4,42 & 15,8 & 0,395 & 383 & 6,22 & 13,8 & 0,391 & 425 & 7,1 & 13,5 & 0,338 & 432 & 5,1 \\
\hline & \multirow{2}{*}{ II } & 8 & 8,9 & 0,332 & 231 & 3,35 & 14,3 & 0,392 & 320 & 6,28 & 13,2 & 0,381 & 365 & 5,86 & 10,1 & 0,335 & 317 & 7,63 \\
\hline & & 7 & 11,2 & 0,372 & 248 & 4,01 & 10,8 & 0,385 & 401 & 6,13 & 14,6 & 0,351 & 400 & 5,72 & 11,8 & 0,298 & 418 & 6,85 \\
\hline \multirow{4}{*}{ Tartar } & \multirow{2}{*}{1} & 8 & 9,7 & 0,375 & 345 & 3,22 & 13,8 & 0,423 & 358 & 5,25 & 21,2 & 0,385 & 379 & 8,92 & 18,8 & 0,442 & 418 & 11,1 \\
\hline & & 7 & 10,1 & 0,382 & 348 & 4,42 & 12,4 & 0,385 & 372 & 6,13 & 18,6 & 0,376 & 385 & 8,43 & 14,2 & 0,325 & 433 & 4,8 \\
\hline & \multirow{2}{*}{ II } & 8 & 7,6 & 0,338 & 228 & 3,18 & 10,1 & 0,331 & 313 & 4,15 & 16,2 & 0,393 & 370 & 5,42 & 17,5 & 0,337 & 343 & 8,6 \\
\hline & & 7 & 8,3 & 0,343 & 243 & 4,01 & 11,8 & 0,375 & 395 & 5,12 & 14,8 & 0,343 & 395 & 7,55 & 9,8 & 0,301 & 420 & 4,3 \\
\hline \multirow{4}{*}{ Gyrmyzygul-1 } & \multirow{2}{*}{1} & 8 & 15,45 & 0,412 & 301 & 6,18 & 20,9 & 0,523 & 276 & 7,12 & 15,8 & 0,362 & 295 & 6,9 & 14,9 & 0,418 & 318 & 5,43 \\
\hline & & 7 & 13,2 & 0,433 & 307 & 5,76 & 10,9 & 0,478 & 325 & 5,81 & 10,2 & 0,345 & 322 & 5,98 & 7,15 & 0,315 & 344 & 4,35 \\
\hline & \multirow{2}{*}{ II } & 8 & 14,82 & 0,375 & 295 & 5,8 & 13,5 & 0,368 & 281 & 5,42 & 12,9 & 0,301 & 290 & 5,76 & 7,88 & 0,268 & 313 & 4,62 \\
\hline & & 7 & 11,86 & 0,333 & 316 & 5,28 & 11,6 & 0,325 & 293 & 4,95 & 7,55 & 0,258 & 316 & 4,83 & 2,22 & 0,198 & 305 & 3,15 \\
\hline \multirow{4}{*}{ Tale 38} & \multirow{2}{*}{1} & 8 & 9,58 & 0,281 & 289 & 4,42 & 25,4 & 0,461 & 257 & 6,72 & 20,3 & 0,648 & 301 & 7,92 & 15,9 & 0,343 & 381 & 5,82 \\
\hline & & 7 & 12,25 & 0,501 & 317 & 5,75 & 16,7 & 0,572 & 308 & 6,95 & 13,7 & 0,628 & 333 & 6,95 & 8,62 & 0,225 & 362 & 4,43 \\
\hline & \multirow{2}{*}{ II } & 8 & 8,33 & 0,223 & 283 & 3,35 & 19,8 & 0,442 & 259 & 6,41 & 16,8 & 0,305 & 276 & 6,38 & 9,43 & 0,285 & 300 & 4,28 \\
\hline & & 7 & 13,9 & 0,338 & 280 & 4,42 & 10,8 & 0,401 & 312 & 5,28 & 6,55 & 0,298 & 335 & 4,53 & 6,54 & 0,255 & 318 & 3,55 \\
\hline
\end{tabular}

Note: I - irrigated; II - not irrigated

1. Pn: Net photosynthetic rate $\left(\mathrm{mmol} \mathrm{CO}_{2} \mathrm{~m}^{-2} \mathrm{~s}^{-1}\right)$ :

2. Gs: Stomatal conductance $\left(\mathrm{mol} \mathrm{H}_{2} \mathrm{O} \mathrm{m}^{-2} \mathrm{~s}^{-1}\right)$,

3. Ci: Intercellular $\mathrm{CO}_{2}$ concentration $\left(\mathrm{mmol} \mathrm{CO}_{2} \mathrm{~mol} 1 / 2\right)$

4. E: Transpiration rate $\left(\mathrm{mol} \mathrm{H}_{2} \mathrm{O} \mathrm{m}^{-2} \mathrm{~s}^{-1}\right)$;

The highest intensity is characteristic of almost formed leaves. With a further increase in leaf age (aging process), the intensity of photosynthesis decreases. The intensity of the photosynthesis is affected by the age of the entire plant. In most annual plants, the intensity of photosynthesis increases during ontogenesis and reaches a maximum during the tubing

\section{REFERENCES}

1. Aliyev J.A. Physiological leaves of what breeding tolerant to water stress wheat in global environment proceedings of the 6 th intern. Wheat conference Jun 5-9/26. 2000, Budapest. Hungary, V.9. p. $693-698$

2. Beadle C L, Jarvis PG. Effects of shoot water status on some photosynthetic partial processes in Sitka spruce. Physiologia Plantarum. 1977; 41: 7-13.

3. Björkman O, Powles SB. Inhibition of photosynthetic reactions under water stress: interaction with light level. Planta. 1984;161:490-504.

4. Brodribb T. Dynamics of changing intercellular $\mathrm{CO}_{2}$ concentration $(\mathrm{Ci})$ during drought and determination of minimum functional Ci. Plant Physiology. 1996;111:179-185.

5. Cornic G, Massacci A. Leaf photosynthesis under drought stress. In: Baker NR, ed. Photosynthesis and the Environment. The Netherlands: Kluwer Academic Publishers. 1996.

6. Flexas J, Escalona JM, Medrano H. Water stress induces different levels of photosynthesis and electron transport rate regulations in grapevines. Plant, Cell and Environment. 1999b;22:39-48. and flowering phases. After flowering, the photosynthesis rate in the leaves decreases. It has been shown that the process of photosynthesis is affected not only by the calendar age of the leaf, but also by the total age of the entire plant organism. Leaves of the same calendar age, but formed on an older plant, have a reduced intensity of photosynthesis.

7. Gunasekera D, Berkowitz GA. Use of transgenic plants with Rubisco antisense DNA to evaluate the rate limitation of photosynthesis under water stress. Plant Physiology.1993;103:629-35.

8. Johnson R C, Mornhinweg DW, Ferris DM, Heitholt JJ. Leaf photosynthesis and conductance of selected Triticum species at different water potentials. Plant Physiology. 1987;83:1014-1017.

9. Lawlor D.W. Integration of biochemical processes in the physiology of water stressed plants. In: Marcelle $\mathrm{R}$, Clijters $\mathrm{H}$, von Puche M, eds. Effects of stress on photosynthesis. The Hague, Boston, London: Martinus Nijhoff/Dr W. Junk Publishers. 1983.

10. Medrano H, Escalona JM, Bota J, Gul as J, Flexas J. Regulation of photosynthesis of C3 plants in response to progressive drought: the stomatal conductance as a reference parameter. Annals of Botany (in press). 2002.

11. Tamraz H. Tamrazov. The research of drought influence to the devolepment dynamics of wheat plant and to the change of morphophysiological indicators. International conference on. New Approaches in Biotechnology \& Biosciences "NABB-2016"-feb (18-20. 2016;11. 